\title{
RADIOCARBON DATES OF PEATS FROM NORTH PACIFIC NORTH AMERICA*
}

\author{
CALVIN J. HEUSSER
}

American Geographical Society, New York, N. Y.

ABSTRACT. Ages are presented for 17 late-Pleistocene peat samples from sections that range from Karluk on Kodiak Island, Alaska to Port Orford, Oregon. Pollen and peat stratigraphy of the sections is used to interpret the environments prevailing at and since the time of sample deposition. The late-glacial at more southerly Pacific coastal Alaskan sites is dated at ca. 10,800 B.P. and the postglacial at ca. 10,000 B.P. At northerly coastal sites these intervals begin somewhat later. Regression rates for sealevel are given for a number of sites along this coast. Sample ages from two Oregon lakes suggest eustatic transgression ca. 5000 B.P. during the Hypsithermal interval.

\section{INTRODUCTION}

In the course of obtaining peat sections for a pollen- and peat-stratigraphic study, entitled "Late-Pleistocene Environments of the North Pacific Coast of North America" under Office of Naval Research contract, 17 samples were collected for dating. The collection was made to lay the base for a chronology. A grant from the National Science Foundation provided for the age determinations which were made by Isotopes Inc., Westwood, New Jersey in 1958.

The method of dating each sample is essentially that described by Broecker and others, 1956. In short, sufficient sample, estimated on the basis of carbon content, is burned, and the $\mathrm{CO}_{2}$ evolved is processed to remove impurities. Radon, one of these, is removed by converting purified $\mathrm{CO}_{2}$ to $\mathrm{CaCO}_{3}$ through reaction with $\mathrm{CaO}$ at $750^{\circ} \mathrm{C}$. The $\mathrm{CO}_{2}$ is re-evolved and stored or counted. Counting is proportional counting of $\mathrm{CO}_{2}$ at 2 atmospheres pressure, and each sample is counted at least twice. Accuracy of the determination of $\mathrm{C}^{14}$ content is believed to be correct to within $3 \%$ or less. Counting error contributes about $2 \%$, and other errors, such as measurement of pressure and temperature, amount to less than $1 \%$.

Samples range from near Karluk on Kodiak Island, Alaska to the vicinity of Port Orford, Oregon. All were gathered with a Hiller sampler except I (AGS ) -5 from Alaganik, Alaska which was taken from an exposed section. All sampling was done between July and September 1956 by the author and A. C. Hawbecker. This collection of samples was planned to date the lateglacial and postglacial along this coast and late-Pleistocene events such as glaciation, volcanism, and changes in land-sealevel relations. A large portion of the samples is from the Alaskan "Tertiary Province" between the mouth of the Copper River and Icy Point. These were taken with the object of dating the prominent series of marine terraces found there. Pollen profiles for the peat sections disclose the environment prevailing at the time represented by the dated samples. In addition, they make possible stratigraphic correlation and age estimates of sections for which no dates are available. Other lists containing particularly interesting dates dealing with this coast have been prepared by Lamont Geological Observatory (Kulp and others, 1951, 1952; Broecker and others, 1956; Broecker and Kulp, 1957; E. A. Olson, personal

* These findings were presented in part at the Ninth Alaskan Science Conference, University of Alaska, on September 5, 1958 in a paper entitled, "Late-Pleistocene Environments and Chronology of Pacific Coastal Alaska". 
communication), U. S. Geological Survey (Suess, 1954; Rubin and Suess, 1955, 1956; Rubin and Alexander, 1958), and Yale Geochronometric Laboratory (Preston and others, 1955; Barendsen and others, 1957).

ACKNOWLEDGMENTS

Support of these studies by the National Science Foundation and the Office of Naval Research is much appreciated; in addition, the assistance of the following is gratefully acknowledged: A. C. Hawbecker, Fresno State College, California; Alaskan Geology Branch, U. S. Geological Survey, Menlo Park, California, particularly Don J. Miller; Commanding Officer, Kodiak Naval Air Station, Alaska; Clyde Maycock, Cordova, Alaska; Kenneth Loken, Juneau, Alaska; and Phillips Petroleum Company.

\section{SAMPLE DESCRIPTIONS}

\section{I(AGS)-1. Karluk, Alaska}

$3470 \pm 180$

Moss peat from base of a $3.5-\mathrm{ft}$ section of muskeg located on a bench just E of Karluk ( $57^{\circ} 34^{\prime} \mathrm{N}$ Lat, $154^{\circ} 28^{\prime} \mathrm{W}$ Long) on the south side of the lagoon at the mouth of Karluk River, alt. ca. $100 \mathrm{ft}$. Pollen profiles reveal inception of muskeg resulted from change to cooler, more humid climate; the proportion of heaths, ferns, and sphagnum mosses increases upward in the section whereas alders and grasses decrease. Comment: sample age and succeeding climatic trend show a relationship to southeastern Alaska on the basis of L-106B, $3500 \pm 250$ (Kulp and others, 1952) and peat and pollen studies (Heusser, $1953)$.

\section{I (AGS)-2. Kodiak, Alaska}

$8870 \pm 300$

Basal sedge peat from a 7 -ft section in muskeg situated near Spruce Cape, $2.5 \mathrm{mi} \mathrm{NE}$ of Kodiak village $\left(57^{\circ} 49^{\prime} \mathrm{N}\right.$ Lat, $152^{\circ} 21^{\prime} \mathrm{W}$ Long), Kodiak Island, alt. ca. $100 \mathrm{ft}$. A cool, moist early-postglacial environment is indicated by a pollen record dominated by ferns, sedges, and umbellifers. Three noteworthy volcanic ash strata lie above in the section, the uppermost, near-surface stratum representing the 1912 eruption of Mount Katmai in the Aleutian Range. Comment: age approximates the late-glacial-postglacial boundary and may be compared with dates (this date list) from Afognak, Perry Island, and Bering Lake.

I(AGS) -3. Afognak, Alaska

$9350 \pm 320$

Sedge peat from bottom of an 8.3-ft section in muskeg just NW of Afognak village $\left(58^{\circ} 01^{\prime} \mathrm{N}\right.$ Lat, $152^{\circ} 46^{\prime} \mathrm{W}$ Long), Afognak Island, alt. ca. $20 \mathrm{ft}$. Pollen in the sample is very similar to that from Kodiak, although greater proportion of sedges suggests the close of the late-glacial and an environment that was cooler and drier. Three volcanic-ash horizons, stratigraphically correlated with those at Kodiak, overlie the sampled level. Sample age and peat and pollen stratigraphy of entire section show that nearhy marine waters have not transgressed the sile since peat sedimentation began in the early post glacial.

\section{I (AGS) -1. Perry Island, Alaska}

$9440 \pm \mathbf{3 5 0}$

Bottom limnic peat from a depth of $13.2 \mathrm{ft}$ in bog-muskeg just $\mathbf{E}$ of the larger of the two bays on the southern shore of Perry Island $\left(60^{\circ} 41^{\prime} \mathrm{N}^{\top}\right.$ Lat. $147^{\circ} 54^{\prime}$ W Long), northwestern Prince William Sound, alt. ca. $50 \mathrm{ft}$. Cooler 
and drier conditions were present at the time, interpreted as the close of the late-glacial, as shown by the proportion of willow and birch in the pollen assemblage, the balance of which consists largely of ferns, sedges, and alders.

I (AGS) -5. Alaganik, Alaska

$10,390 \pm 350$

Sedge peat forming the base of a 6.6-ft section exposed by construction of the Copper River Highway at Milepost 19 from Cordova $\left(60^{\circ} 27^{\prime} \mathrm{N}\right.$ Lat, $145^{\circ}$ $17^{\prime} \mathrm{W}$ Long), alt. ca. $20 \mathrm{ft}$. Late-glacial pollen in the sample consists of willows, heaths, and sedges and is representative of relatively dry, cold climate. In view of the age of the sample, peat and pollen stratigraphy of the section, and nearness of the site to sealevel, nearby coast has been quite stable for at least the past 10,000 yr. Comment: sample age is earliest late-glacial for this part of the gulf coast. This may be a consequence of early peat deposition from plants that invaded the site from driftless area near Alaganik (Tarr and Martin, 1914).

I (AGS) -6. Katalla I, Alaska

$7650 \pm 330$

Sedge and moss peat underlying slope muskeg at a depth of $7.6 \mathrm{ft}$, situated $0.5 \mathrm{mi} \mathrm{N}$ of Katalla village $\left(60^{\circ} 12^{\prime} \mathrm{N}\right.$ Lat, $144^{\circ} 32^{\prime} \mathrm{W}$ Long $)$, alt. ca. $180 \mathrm{ft}$. High proportion of alder pollen in the sample with higher percentages in horizons overlying in the section is interpreted as representative of pre-early-Hypsithermal time. Comment: marine terraces or indications of elevated former strandlines are present at Katalla at less than $100 \mathrm{ft}$ altitude, although regionally they may be present up to $200 \mathrm{ft}$ or more (D. J. Miller, U. S. Geological Survey, personal communication). Age, pollen spectrum, and altitude of sample compared with ages, pollen spectra, and altitudes of samples from Katalla II, Martin Lake, and Bering Lake (this date list) suggest that Katalla I sample rests upon a former marine site and its age dates marine regression from the surface.

\section{I(AGS) -7. Katalla II, Alaska}

$\mathbf{3 7 7 0} \pm \mathbf{2 0 0}$

Silty limnic peat from base of a $6.3-\mathrm{ft}$ section in muskeg located $0.3 \mathrm{mi}$ $\mathrm{N}$ of Katalla village $\left(60^{\circ} 12^{\prime} \mathrm{N}\right.$ Lat, $144^{\circ} 32^{\prime} \mathrm{W}$ Long $)$, alt. ca. $40 \mathrm{ft}$. Site interpreted to have been previously occupied by marine waters (D. J. Miller, personal communication). Comparison of Katalla II pollen profiles with those from Katalla I section reveals inception of the former deposit in the late Hypsithermal. Comment: rate of marine regression is figured at ca. $3.6 \mathrm{ft} / 100$ yr between 180-ft and 40-ft altitudes in the Katalla district on the basis of Katalla I (this date list) and Katalla II sample ages.

\section{I (AGS) -8. Martin Lake, Alaska}

$6810 \pm 375$

Silty sedge peat at the hase of muskeg, $4.3 \mathrm{ft}$ deep, on a peninsula on the W side of Martin Lake $\left(60^{\circ} 21^{\prime} \mathrm{N}\right.$ Lat, $144^{\circ} 34^{\prime} \mathrm{W}$ Long), ca. $11 \mathrm{mi} \mathrm{N}$ of Katalla, alt. ca. $100 \mathrm{ft}$. Alder is the predominant pollen in the sample, which is of Hypsithermal age. Sample age is interpreted as approximately dating marine regression from the site. Comment: taking into account the Katalla I and II ages (this date list) and the age of the Martin Lake sample, the rate of regression appears as follows in this district: ca. $80 \mathrm{ft}$ in $840 \mathrm{yr}$ since ca. 7650 B.P. or a rate of $9.5 \mathrm{ft} / 100 \mathrm{yr}$; ca. $60 \mathrm{ft}$ additional between 6810 and 3770 B.P. or $2 \mathrm{ft} / 100 \mathrm{yr}$; and ca. $40 \mathrm{ft}$ in the last $3770 \mathrm{yr}$. or $1 \mathrm{ft} / 100 \mathrm{yr}$. 
Sedge peat underlying muskeg, $10.9 \mathrm{ft}$ deep, situated ca. $0.5 \mathrm{mi}$ from NW shore and ca. $10 \mathrm{mi}$ NE of Katalla $\left(60^{\circ} 19^{\prime} \mathrm{N}\right.$ Lat, $144^{\circ} 20^{\prime} \mathrm{W}$ Long $)$, alt. ca. $180 \mathrm{ft}$. Early peat deposition at this site, as indicated by age and proportion of willow pollen in dated sample, is the latter part of the late-glacial, although climate does not appear to have been so cold or so dry during lateglacial time as at other localities given in this list. The upper limit of marine transgression in the vicinity of this sample site is unknown.

\section{I(AGS)-10. Munday Creek, Alaska}

$10,820 \pm 420$

Basal sedge peat from a depth of $23.4 \mathrm{ft}$ in muskeg just $\mathrm{W}$ of Munday Creek, ca. $1 \mathrm{mi}$ from the beach and ca. $10 \mathrm{mi}$. NE of Icy Cape $\left(60^{\circ} 01^{\prime} \mathrm{N}\right.$ Lat, $141^{\circ} 57^{\prime} \mathrm{W}$ Long), alt. ca. $230 \mathrm{ft}$. This peat, according to D. J. Miller (personal communication), rests on a terrace, the uppermost of several definitely determined as marine in this district. Pollen in the sample is late-glacial and consists predominantly of sedges with smaller amounts of other types characteristic of late-glacial deposits, such as heath, willow, and umbellifer. These facts provide an approximate regression rate of over $2 \mathrm{ft} / 100 \mathrm{yr}$ from the late-glacial to the present sealevel stand. Comment: rate from a lower terrace at ca. $40 \mathrm{ft}$ has been ca. $3.8 \mathrm{ft} / 100 \mathrm{yr}$ as indicated by W.369, $1050 \pm$ 160 (Rubin and Alexander, 1958). Sample age and pollen content may be compared with Lamont dates and comments for North Pacific coastal samples (L-297C, 10,850 \pm 800; L-297D, 10,300 \pm 400, Broecker and Kulp, 1957) and for Alagnik site (this date list). Postglacial time ensued at this site ca. 10,000 B.P.

\section{I(AGS)-11. Grand Plateau Glacier, Alaska $\quad 1210 \pm 200$}

Sedge peat lowermost at a $6.6-\mathrm{ft}$ depth in muskeg ca. $3 \mathrm{mi} \mathrm{SE}$ of the glacier, ca. $5 \mathrm{mi} \mathrm{NW}$ of the mouth of Sea Otter Creek $\left(58^{\circ} 57^{\prime} \mathrm{N} \mathrm{Lat,} 138^{\circ}\right.$ $00^{\prime} \mathrm{W}$ Long), and ca. $0.5 \mathrm{mi}$ from the beach, alt. ca. $30 \mathrm{ft}$. Site appears to have been formerly a lagoon which became fresh as a result of rising land, falling sealevel, or both. Regression rate for sealevel from this stand to the present one is ca. $2.5 \mathrm{ft} / 100 \mathrm{yr}$. Comment: sample age and altitude show close relationship to U. S. Geological Survey sample from Munday Creek at ca. 40ft altitude (W-369, $1050 \pm 160$; Rubin and Alexander, 1958).

\section{I (AGS)-12. Northwest Lituya Bay I, Alaska $\quad 8140 \pm 390$}

Bottom ligneous peat from a depth of $10.2 \mathrm{ft}$ in muskeg resting upon the upper of a pair of marine terraces located ca. $13 \mathrm{mi} \mathrm{NW}$ of Lituya Bay $\left(58^{\circ}\right.$ $43^{\prime} \mathrm{N}$ Lat, $137^{\circ} 45^{\prime} \mathrm{W}$ Long) and ca. $1.5 \mathrm{mi}$ from the beach, alt. ca. $300 \mathrm{ft}$. Fern spores dominate the plant microfossils in the sample which dates from the early-postglacial cool, humid environment. Rate of regression of the ocean from this position to its present stand has been ca. $3.7 \mathrm{ft} / 100 \mathrm{yr}$.

\section{I(AGS)-13. Northwest Lituya Bay II, Alaska $\quad 6890 \pm 350$}

Basal ligneous peat sampled from a depth of $7.3 \mathrm{ft}$ in muskeg ca. $0.25 \mathrm{mi}$ SW of Northwest Lituya Bay I site $\left(58^{\circ} 43^{\prime} \mathrm{N}\right.$ Lat, $137^{\circ} 45^{\prime} \mathrm{W}$ Long), alt. ca. $110 \mathrm{ft}$. Pollen stratigraphy of peat section indicates sample dates from Hypsithermal time. Regression rate from this stand of the ocean is ca. 1.6 $\mathrm{ft} / 100 \mathrm{yr}$. Comment: on the basis of this age and that of sample from North- 
west Lituya Bay I (this date list), the relative position of land and sealevel changed ca. $190 \mathrm{ft}$ in $1250 \mathrm{yr}$ or ca. $15.2 \mathrm{ft} / 100 \mathrm{yr}$.

I(AGS)-14. Southeast Lituya Bay, Alaska

$\mathbf{2 7 9 0} \pm \mathbf{2 5 0}$

Sedge peat from bottom of muskeg at a depth of $3.3 \mathrm{ft}$; site $\left(58^{\circ} 36^{\prime} \mathrm{N}\right.$ Lat, $137^{\circ} 34^{\prime} \mathrm{W}$ Long) lies ca. $3 \mathrm{mi} \mathrm{SE}$ of the mouth of Lituya Bay, $1.5 \mathrm{mi}$ NW of Steelhead Creek, and $0.25 \mathrm{mi}$ from the ocean, alt. ca. $100 \mathrm{ft}$. Muskeg rests on what appears to be the highest of three marine terraces above the present ocean stand. High proportion of sphagnum spores, abundance of pollen of arboreal conifers in the overlying section, and sample age suggest contemporaneity with post-Hypsitherinal interval. Regression rate between this and the present stand of the ocean is ca $3.6 \mathrm{ft} / 100 \mathrm{yr}$. Comment: regression rate on the basis of a sample dated from a $150-\mathrm{ft}$ marine terrace ca. $13 \mathrm{mi}$ $\mathrm{SE}$ of this site, W-405, $3250 \pm 200$ (Rubin and Alexander, 1958), is ca. $4.6 \mathrm{ft} / 100 \mathrm{yr}$. Comparison with the Southeast Lituya Bay sample age and altitude suggests a rate of regression between the $150-\mathrm{ft}$ and $100-\mathrm{ft}$ stands SE of the bay as ca. $10.9 \mathrm{ft} / 100 \mathrm{yr}$. Also, comparison of Southeast Lituya Bay age and that from Northwest Lituya Bay II (this date list) (both sites at nearly the same altitude) reveals that the ocear withdrew from the latter site much earlier. Such a difference between sites at practically the same altitude NW and SE of the bay suggests variations in local tectonic activity.

I (AGS)-15. Seaview, Washington

$2950 \pm 150$

Bottom sedge peat at a depth of $10.9 \mathrm{ft}$ in muskeg $\left(46^{\circ} 19^{\prime} \mathrm{N}\right.$ Lat, $124^{\circ}$ $03^{\prime} \mathrm{W}$ Long) situated at the end of an abandoned dirt road that leads off the $\mathrm{S}$ side of State Highway 12, ca. $1.25 \mathrm{mi}$ E of Seaview, alt. ca. $10 \mathrm{ft}$. Location is north of the mouth of the Columbia River in Pacific County. Pollen profiles from section of the muskeg show an increase upward of lodgepole pine at the expense of forest conifers Sitka spruce and western hemlock; fern and sphagnum spores also increase upward. A period of storminess and dune instability and of cool, moist climate with variations is inferred to have occurred after the time represented by this sample age. Muskeg resting at present sealevel may have begun to form with the laying down of the southern portion of the Long Beach spit, and, accordingly, sample age may date this event. Comment: arboreal pollen profiles by Hansen (1944) from nearby llwaco show essentially similar form to Seaview profiles.

I (AGS)-16. Devils Lake, Oregon

$6300 \pm 275$

Peat consisting of limnic and ligneous remains from a depth of $38.6 \mathrm{ft}$ in section removed from a wooded bog found on the $\mathrm{W}$ shore of Devils Lake $\left(44^{\circ} 58^{\prime} \mathrm{N}\right.$ Lat, $124^{\circ} 00^{\prime} \mathrm{W}$ Long), ca. $1 \mathrm{mi} \mathrm{NE}$ of the outlet, and less than $1 \mathrm{mi} \mathrm{E}$ of the village of Oceanlake, Lincoln County, alt. ca. $15 \mathrm{ft}$. Approximately $23 \mathrm{ft}$ of the section are below present sealevel. Pollen profiles for the section show a prominence of two brackish-water indicators, Ruppia and Chenopodiaceae, with two intervals of nondeposition of pollen, between ca. $20 \mathrm{ft}$ and ca. $30 \mathrm{ft}$. This portion of the section is interpreted as representing a time when Devils Lake was a saltwater lagoon. Below the $30-\mathrm{ft}$ level in the section, some sediments appear to have formed in slightly brackish water, but above the 20-ft level, essentially freshwater conditions are manifest. Comment: sample age and section stratigraphy suggest eustatic sealevel rise during the Hypsi- 
thermal, reaching a maximum ca. $5000 \mathrm{yr}$ B.P. between ca. $20 \mathrm{ft}$ and ca. $30 \mathrm{ft}$ in the section. In addition, it appears likely that the inception of the Devils Lake deposit is related to the early phase of the eustatic rise of the Pacific Ocean that ultimately resulted in the formation of the Older Peron Terrace, Australia, which dates from ca. 5000 B.P. (Fairbridge, 1958). If the two levels of nondeposition of pollen at this site represent two separate transgressions, the lower level may be related to the Older Peron Terrace whereas the upper one may bear a relationship to the Younger Peron Terrace, dating from ca. 3600 B.P. (Fairbridge, 1958 ).

\section{I(AGS)-17. Garrison Lake, Oregon}

$6720 \pm 250$

Basal limnic-ligneous peat from a depth of $42.9 \mathrm{ft}$ in section from the $\mathrm{NW}$ arm of Garrison Lake $\left(42^{\circ} 06^{\prime} \mathrm{N}\right.$ Lat, $124^{\circ} 31^{\prime} \mathrm{W}$ Long), less than $0.5 \mathrm{mi}$ from the ocean, $6 \mathrm{mi}$ southerly from Cape Blanco, and $1.5 \mathrm{mi} \mathrm{NW}$ of Port Orford, Curry County, alt. ca. $5 \mathrm{ft}$. Almost the entire section is beneath present sealevel, and, although it is largely a freshwater deposit, pollen profiles disclose several possibly mildly brackish intervals of deposition with one strongly brackish from ca. 33 to ca. $36 \mathrm{ft}$, this latter as indicated by the Ruppia profile. Using the sample age as a datum from which to estimate, this strongly brackish interval is dated at ca. 5000 B.P. and suggests eustatic transgression. Comment: age of the sample and position of the Ruppia zone in the overlying sediments in this section generally corroborate data from Devils Lake (this date list). If, in reality, two separate transgressions have occurred at Devils Lake, pollen profiles from Garrison Lake suggest that the single Ruppia peak is related to the older transgression. There appears to be no evidence of a younger transgression at this site.

\section{REFERENCES}

Barendsen, G. W., Deevey, E. S., and Gralenski, L. J., 1957, Yale natural radiocarbon measurements III: Science, v. 126, p. 908-919.

Broecker, W. S., and Kulp, J. L., 1957, Lamont natural radiocarbon measurements IV: Science, v. 126 , p. 1324-1334.

Broecker, W. S., Kulp, J. L., and Tucek, C. S., 1956, Lamont natural radiocarbon measurements III: Science, v. 124 , p. 154-165.

Fairbridge, R. W., 1958, Dating the latest movements of the Quaternary sea level: New York Acad. Sci. Trans., ser, 2, v. 20, p. 471-482.

Hansen, H. P., 1944, Further pollen studies of peat bogs on the Pacific coast of Oregon and Washington: Torrey Bot. Club Bull., v. 71, p. 627-636.

Heusser, C. J., 1953, Radiocarbon dating of the thermal maximum in southeastern Alaska: Ecology, v. 34, p. 637-640.

Kulp, J. L., Feely, H. W., and Tryon, L. E., 1951, Lamont natural radiocarbon measurements, I: Science, v. 114, p. 565-568.

Kulp, J. L., Tryon, L. E., Eckelman, W. R., and Snell, W. A., 1952, Lamont natural radiocarbon measurements, II: Science, v. 116, p. 409-414.

Preston R. S., Person, Elaine, and Deevey, E. S., 1955, Yale natural radiocarbon measurements II: Science, v. 122, p. $954-960$.

Rubin, Meyer, and Alexander, Corrinne, 1958, U. S. Geological Survey radiocarbon dates IV: Science, v. 127, p. 1476-1487.

Rubin, Meyer, and Suess, H. E., 1955, U. S. Geological Survey radiocarbon dates II: Science, v. 121 , p. $481-488$.

- 1956, U. S. Geological Survey radiocarbon dates III: Science, v. 123, p. $442-$ 448.

Suess, H. E., 1954, U. S. Geological Survey radiocarbon dates I: Science, v. 120, p. 467473.

Tarr, R. S., and Martin, Lawrence, 1914, Alaskan glacier studies of the National Geographic Society in the Yakutat Bay, Prince William Sound and lower Copper River regions: Washington, Nat. Geog. Soc., 498 p. 